\title{
Human papillomavirus in lung carcinomas among three Latin American countries
}

\author{
ANDRES CASTILLO ${ }^{1}$, FRANCISCO AGUAYO ${ }^{2}$, CHIHAYA KORIYAMA ${ }^{1}$, KAREM SHUYAMA ${ }^{1}$, \\ SUMINORI AKIBA ${ }^{1}$, ROBERTO HERRERA-GOEPFERT ${ }^{3}$, EDWIN CARRASCAL $^{4}$, \\ GERMAN KLINGE ${ }^{5}$, JUVENAL SÁNCHEZ ${ }^{5}$ and YOSHITO EIZURU ${ }^{2}$
}

\begin{abstract}
${ }^{1}$ Department of Epidemiology and Preventive Medicine, Graduate School of Medical and Dental Sciences, Kagoshima University, Kagoshima; ${ }^{2}$ Division of Oncogenic and Persistent Viruses, Center for Chronic Viral Diseases, Graduate School of Medical and Dental Sciences, Kagoshima University, Kagoshima, Japan; ${ }^{3}$ Department of Pathology, Instituto Nacional de Cancerologia, México City, Mexico; ${ }^{4}$ Department of Pathology, Faculty of Health Sciences, University of Valle, Sede San Fernando, Cali, Colombia; ${ }^{5}$ Instituto de Enfermedades Neoplásicas, MINSA, Lima, Peru
\end{abstract}

Received July 25, 2005; Accepted November 7, 2005

\begin{abstract}
The presence of human papillomavirus (HPV) genome in lung carcinomas has been reported worldwide but its frequency varies from country to country. We examined HPV genome in 36 lung carcinomas, consisting of 14 squamous cell carcinomas, 13 adenocarcinomas, and 9 small cell carcinomas, collected from Colombia, Mexico and Peru. PCR analysis using $G P 5^{+} / G P^{+}$primers, combined with Southern blot hybridization, found the presence of HPV genome in $10(28 \%)$ of 36 cases. This percentage is similar to the value of $22 \%$ reported by Syrjänen, who conducted a meta-analysis of nearly 2500 lung carcinomas examined to date. Genotype analysis revealed that the most predominant genotype was HPV-16 (7 cases), followed by HPV-18 ( 2 cases) and HPV-33 (1 case). HPV-16 was more frequently found among female than male cases $(\mathrm{P}=0.008)$ but was not detected in any adenocarcinoma cases. On the other hand, HPV-18 and HPV-33 were detected only among male cases. These HPV genotypes were detected only in adenocarcinomas, and all the HPV genotypes detected in this histological type were HPV-18 or HPV-33. The frequency of HPV-16 positive cases among all the HPV positive cases differed in the sexes $(\mathrm{P}=0.033)$ and differed in the three histological types $(\mathrm{P}=0.017)$. The presence of HPV tended to be.more frequent in well-differentiated tumors when squamous cell carcinomas and adenocarcinomas were combined.
\end{abstract}

Correspondence to: Dr Suminori Akiba, Department of Epidemiology and Preventive Medicine, Kagoshima University Graduate School of Medical and Dental Sciences, 8-35-1 Sakuragaoka, Kagoshima 890-8544, Japan

E-mail: akiba@m.kufm.kagoshima-u.ac.jp

Key words: HPV, lung cancer, Latin America
However, it was not statistically significant $(\mathrm{P}=0.093)$. Neither p16 nor p53 expression in carcinoma cells was related to the proportion of HPV-positive cases. In conclusion, high-risk HPV DNA was detected in $28 \%$ of lung carcinomas. The predisposition of HPV-16 to female cases and to non-adenomatous carcinomas warrants further investigation.

\section{Introduction}

Human papillomavirus (HPV) is a double stranded DNA virus, and is an established etiological agent causing cancer of the uterine cervix. A large-scale international study detected highrisk HPV in $99.7 \%$ of cervical carcinomas (1) and persistent infection with high-risk HPV is considered its 'necessary cause' $(2,3)$. Furthermore, HPV is suspected to cause extragenital cancers, including cancers of the oral cavity, larynx, esophagus, and lung. However, the role of HPV infection in the pathogenesis of those malignancies is still controversial (4-6).

Lung cancer is the leading cause of death from malignant tumors, and its incidence is rapidly rising in developing countries (7). Although smoking is the most important risk factor of this malignancy, its worldwide epidemic is exacerbated by additional factors, including indoor radon exposure, environmental arsenic contamination and atmospheric pollution, and, possibly, by HPV infection (7). Etiological involvement of HPV in development of lung cancer was originally postulated by Syrjänen $(8,9)$ but the causeeffect relationship is yet to be established (6). Most importantly, HPV DNA integration into host-cell DNA, which is considered an important process in development of cervical cancer, has not been confirmed in lung cancer (6).

Lung cancer harboring HPV DNA is not rare; the metaanalysis conducted by Syrjänen (10) revealed that HPV DNA is detected in as much as $21.7 \%$ of the 2468 lung carcinomas analyzed to date. HPV DNA can also be detected in epidermoid esophageal carcinomas. The frequency of HPV-related esophagus carcinomas varies widely worldwide $(10,11)$. While the geographical distribution of HPV-related lung 
Table I. Sequences of the oligonucleotides used as PCR primers.

\begin{tabular}{llll}
\hline Gene & Primers & \multicolumn{1}{c}{ Sequences } & Size (bp) \\
\hline HPV L1 & $G P 5^{+}$ & 5'-TTTGTTACTGTGGTAGATACTAC-3' & 150 \\
& $G P 6^{+}$ & 5'-GAAAATAAACTGTAAATCATATTC-3' & 110 \\
Human ß-globin & $P C O 3$ & 5'-ACACAACTGTGTTCACTAGC-3' & \\
& $P C O 4$ & 5'-CAACTTCATCCACGTTCACC-3' & \\
\hline
\end{tabular}

carcinoma is much less clear, a high frequency was reported by studies in southern Japan (11) and Taiwan (12). In a study conducted in Taiwan, Cheng et al reported that a high incidence of lung cancer among non-smoking women may be explained by a high prevalence of HPV-16/18 infection (12).

To our knowledge, there is only one study from Latin America reporting the presence of HPV in lung carcinomas (13). In this Chilean study, 6 of 13 squamous cell carcinoma cases $(42 \%)$ had HPV DNA. The present study examined the HPV genome and genotype in lung carcinoma specimens among patients from Colombia, Mexico and Peru.

\section{Materials and methods}

Subjects. The present study examined HPV genome in carcinoma tissues obtained from 36 lung cancer cases diagnosed in the following institutes of three Latin American countries: 7 squamous cell carcinoma and 8 adenocarcinoma cases diagnosed at Unidad de Patologia, Hospital General de Mexico, Mexico, during the period from 1975 to $1981 ; 3$ squamous cell carcinoma, 2 adenocarcinoma and 6 small cell carcinoma cases diagnosed at Hospital Universitario del Valle in Cali, Colombia, during the period from 1996 to 2001; and 4 squamous cell carcinoma, 3 adenocarcinoma and 3 small cell carcinoma cases diagnosed at National Cancer Institute, INEN of Peru, in 1996. The institutional review board of the Graduate School of Medical and Dental Sciences, Kagoshima University, Japan, approved the present study.

DNA extraction. Sections $(10 \mu \mathrm{m})$ were prepared from each formalin-fixed paraffin-embedded sample. The specimens were treated with $1 \mathrm{ml}$ of xylene, and then with $1 \mathrm{ml}$ of ethanol. After centrifugation, the pellet was resuspended in digestion buffer (50 mM Tris-Cl pH 8.0, 1 mM EDTA pH 8.0, 0.5\% Tween 20) containing $200 \mu \mathrm{g}$ of Proteinase $\mathrm{K}$ (Invitrogen) and incubated at $56^{\circ} \mathrm{C}$ for $24 \mathrm{~h}$. After the incubation, the solution was heated at $100^{\circ} \mathrm{C}$ for $10 \mathrm{~min}$ and centrifuged. An aliquot of the supernatant was directly used for PCR.

PCR, Southern blot hybridization and sequencing. HPV amplification with $G P 5^{+} / G P 6^{+}$primers (Table I) $(14,15)$ was made in a reaction mix containing $2.5 \mu \mathrm{l}$ of template DNA, 200- $\mu \mathrm{M}$ dNTP, $0.5 \mu \mathrm{M}$ of each primer and 1.0 U Taq DNA polymerase (Takara, Japan) in a total volume of $25 \mu \mathrm{l}$ of reaction buffer (50 $\mathrm{mM} \mathrm{KCl}, 20 \mathrm{mM}$ Tris-Cl, $\mathrm{pH} \mathrm{8.3).} \mathrm{The}$ conditions of amplification were as follows: initial denaturation to $95^{\circ} \mathrm{C}$ for $4 \mathrm{~min}$; subsequent 45 cycles consistent of $95^{\circ} \mathrm{C}$ for $1 \mathrm{~min}, 40^{\circ} \mathrm{C}$ for $2 \mathrm{~min}$ and $72^{\circ} \mathrm{C}$ for $1.5 \mathrm{~min}$ and final extension at $72^{\circ} \mathrm{C}$ for $5 \mathrm{~min}$.

B-globin amplification with PCO3/PCO4 (110 bp) primers was used as the internal positive control (Table I). PCR condition was as follows: the initial denaturation at $95^{\circ} \mathrm{C}$ for $4 \mathrm{~min}, 40$ cycles with the cycling profile of $95^{\circ} \mathrm{C}$ for $1 \mathrm{~min}$, $52^{\circ} \mathrm{C}$ for $1 \mathrm{~min}$ and $72^{\circ} \mathrm{C}$ for $2 \mathrm{~min}$ and the final extension for $5 \mathrm{~min}$ at $72^{\circ} \mathrm{C}$. DNA purified from HeLa cells containing HPV-18 was used as external positive control.

The amplified products were revealed through electrophoresis with $3.0 \%$ agarose gels at 100 volts for $30 \mathrm{~min}$. After electrophoresis, the DNA was transferred onto Hybond $\mathrm{N}^{+}$nylon transfer membrane (Amersham, UK) by capillary blotting using $0.4 \mathrm{~N} \mathrm{NaOH}$. The generic GP5 ${ }^{+} / \mathrm{GP}^{+} \mathrm{PCR}$ products amplified from the cloned HPV-6 and -18 were purified from agarose gel by QIAEX II Extraction Kits (Qiagen GmbH and Qiagen Inc., Hilden, Germany) and used as probes to detect HPV-6/11 and HPV-16/18, respectively. The hybridization was made at $42^{\circ} \mathrm{C}$ overnight and then the membranes were washed at $42^{\circ} \mathrm{C}$ with solution containing $6 \mathrm{M}$ urea, $0.4 \%$ SDS and $0.5 \mathrm{X} \mathrm{SSC}$ buffer. For the detection of HPV genome, hybridization was carried out using the ECL direct labeling and detection kit (Amersham, UK) according to the instructions of the manufacturer.

Amplified PCR products that appeared as a visible band after ethidium bromide staining were purified using QIAGEN PCR purification kit and were directly sequenced by fluorescent dye-labeled dideoxynucleotides and cycle sequencing methods using the Big DyeTerminator Cycle Sequencing Kit (PE Applied Biosystems, NJ, USA). In the samples where positive signal was seen only after Southern blot analysis but not in the agarose-gel electrophoresis, the second round of PCR was conducted. Sequence analysis was performed on the ABI PRISM 310 Genetic Analyzer (PE Applied Biosystems). The nucleotide sequences were aligned and compared with those of known HPV types available through the GenBank database (NCBI, National Institute of health, Bethesda, MD, USA) by using BLAST 2.2 (http:// www.ncbi.nih.gov/BLAST/).

Immunostaining for p16INK4a and p53 proteins. Sections of paraffin-embedded block $(2-3 \mu \mathrm{m})$ were placed on silanecoated glass slides, and deparaffinized by passage through xylene. The endogenous peroxidase activity was blocked with $0.3 \% \mathrm{H}_{2} \mathrm{O}_{2} /$ methanol, and the slides were then rehydrated with $0.01 \mathrm{~mol} / 1$ sodium phosphate/citrate buffer, $\mathrm{pH}$ 8.0. For antigen retrieval, the slides were heated in $0.01 \mathrm{M}$-citrate 
Table II. Demographic characteristics and histological types of lung carcinomas.

No. Mexico Colombia Peru

\begin{tabular}{lrrrr}
\hline Gender & & & & \\
$\quad$ Male & 22 & 10 & 6 & 6 \\
Female & 14 & 5 & 5 & 4 \\
Age & & & & \\
$\quad \leq 60$ & 12 & 6 & 4 & 2 \\
$60-74$ & 16 & 5 & 5 & 6 \\
$75+$ & 8 & 4 & 2 & 2 \\
Histology & & & & \\
Squamous cell carcinoma & 14 & 7 & 3 & 4 \\
Adenocarcinoma & 13 & 8 & 2 & 3 \\
Small cell carcinoma & 9 & 0 & 6 & 3 \\
Total & 36 & 15 & 11 & 10 \\
\end{tabular}

buffer, $\mathrm{pH} 6.0$, at $95^{\circ} \mathrm{C}$ for $30 \mathrm{~min}$. After rinsing in $0.01 \mathrm{~mol} / 1$ phosphate-buffered saline (PBS), pH 7.4, nonspecific antibody binding was reduced by incubating the sections with $10 \%$ fetal bovine serum in PBS for $30 \mathrm{~min}$. Then, the sections were incubated overnight at $4^{\circ} \mathrm{C}$ with a mouse monoclonal antibody of p16 (1:200 dilutions, GST-p16 ${ }^{\text {INK4 }}$, PharMingen International) or p53 (1:50 dilutions, DO-7, Dako Japan Co., Ltd.). After washing thoroughly with PBS, the slides were incubated with biotinylated horse anti-mouse IgG for $30 \mathrm{~min}$ followed by a 1:100 dilution of the avidinbiotin-peroxidase complex (Vectastain elite ABC kit, Vector Laboratories, Burlingame, CA) for an additional $30 \mathrm{~min}$. The peroxidase signal was visualized by treatment with DAB substrate-chromogen system (Dako) for $8 \mathrm{~min}$. Finally the sections were stained lightly with hematoxylin. Nuclear staining was considered positive for p16 and p53 expression. In statistical analysis, the cases with less than $10 \%$ carcinoma cells stained positive were classified as negative and the other cases were regarded as positive for the expression in both p16 and p53 proteins $(16,17)$.

Statistical analysis. Fisher's exact test was applied to examine associations between HPV status and each clinicopathological factor including p16 and p53 expressions. We used Wilcoxon rank-sum test for the comparison of age distribution. All the $\mathrm{P}$-values presented are two-sided.

\section{Results}

We analyzed 36 lung carcinomas, consisting of 14 squamous cell carcinomas, 13 adenocarcinomas, and 9 small cell carcinomas collected from Mexico, Colombia and Peru (Table II). Twenty-two patients were male $(61 \%)$ and 14 were female $(39 \%)$. The mean age of the patients was $65 \pm 11$ years.

HPV was detected using $G P 5^{+} / G P 6^{+}$primers for PCR and its presence was confirmed by Southern blot analysis. In total, we detected HPV in 10 (28\%) out of 36 cases (Table III).
Table III. Detection of HPV genome in lung carcinomas.

\begin{tabular}{|c|c|c|c|c|}
\hline & No. & $\mathrm{HPV}^{+}(\%)$ & HPV- $(\%)$ & P-value \\
\hline Total & 36 & $10(28)$ & $26(72)$ & \\
\hline $\begin{array}{l}\text { Country } \\
\text { Mexico } \\
\text { Colombia } \\
\text { Peru }\end{array}$ & $\begin{array}{l}15 \\
11 \\
10\end{array}$ & $\begin{array}{l}5(33) \\
4(36) \\
1(10)\end{array}$ & $\begin{array}{r}10(67) \\
7(64) \\
9(90)\end{array}$ & 0.405 \\
\hline $\begin{array}{l}\text { Gender } \\
\text { Male } \\
\text { Female }\end{array}$ & $\begin{array}{l}22 \\
14\end{array}$ & $\begin{array}{l}4(18) \\
6(43)\end{array}$ & $\begin{array}{r}18(82) \\
8(57)\end{array}$ & 0.140 \\
\hline $\begin{array}{l}\text { Histology } \\
\text { Squamous } \\
\text { cell carcinomas } \\
\text { Adenocarcinomas } \\
\text { Small cell carcinoma }\end{array}$ & $\begin{array}{r}14 \\
13 \\
9\end{array}$ & $\begin{array}{l}4(29) \\
3(23) \\
3(33)\end{array}$ & $\begin{array}{r}10(71) \\
10(77) \\
6(67)\end{array}$ & 0.899 \\
\hline $\begin{array}{l}\text { p16INK4a protein } \\
\text { expression }(\%) \\
\geq 80 \\
<80 \\
<10\end{array}$ & $\begin{array}{r}9 \\
7 \\
20\end{array}$ & $\begin{array}{l}2(22) \\
3(43) \\
5(25)\end{array}$ & $\begin{array}{r}7(78) \\
4(57) \\
15(75)\end{array}$ & 0.687 \\
\hline $\begin{array}{l}\text { p53 expression }(\%) \\
\geq 80 \\
<80 \\
<10\end{array}$ & $\begin{array}{r}5 \\
7 \\
24\end{array}$ & $\begin{array}{l}2(40) \\
1(14) \\
7(29)\end{array}$ & $\begin{array}{r}3(60) \\
6(86) \\
17(71)\end{array}$ & 0.645 \\
\hline
\end{tabular}

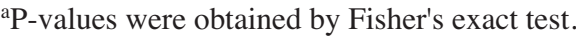

ß-globin gene was successfully amplified by PCR in all subjects.

The proportion of HPV-positive cases did not differ by gender. The mean age at diagnosis among HPV-positive and negative cases were $67 \pm 11$ and $64 \pm 8$, respectively (data not shown in the table). Although HPV-positive cases tended to be older than HPV-negative cases, the difference was not statistically significant ( $\mathrm{P}=0.297$, Mann-Whitney test). In comparison among the three countries, the frequency of HPV-positive cases in Colombia appeared to be lower than the other two countries but the difference among countries was not statistically significant (Table III). The histology of lung cancer or the expression of p16 and p53 proteins in carcinoma cells was not related to the proportion of HPVpositive cases, either.

Genotypes for HPV-16/18 was determined by Southern blot hybridization of PCR products, and confirmed by sequencing. Southern blot analysis could not determine HPV genotype in one case and, therefore, the base sequence of its PCR product was analyzed. Blast analysis of the obtained base sequence revealed its genotype to be HPV-33. We could not detect any HPV-6/11 in the subjects.

Analysis of HPV genotype revealed that the predominant genotype was HPV-16 (7 cases), followed by HPV-18 (2 cases) and HPV-33 (1 case). Table IV-A shows the results examining the frequency of HPV-16 detection. Females accounted for 
Table IV. A. Detection of HPV-16 in lung carcinomas.

\begin{tabular}{|c|c|c|c|c|}
\hline \multirow[b]{3}{*}{ Total } & \multirow{3}{*}{$\begin{array}{c}\text { No. } \\
36\end{array}$} & \multicolumn{2}{|c|}{ No. of the cases $(\%)$} & \multirow[b]{2}{*}{ P-value ${ }^{b}$} \\
\hline & & HPV $-16^{+}$ & $\mathrm{HPV}-16^{-\mathrm{a}}$ & \\
\hline & & 7 (19) & $(81)$ & \\
\hline Country & & & & 0.772 \\
\hline Mexico & 15 & $3(20)$ & $12 \quad(80)$ & \\
\hline Colombia & 11 & $3(27)$ & $(73)$ & \\
\hline Peru & 10 & $1(10)$ & $9 \quad(90)$ & \\
\hline Gender & & & & 0.008 \\
\hline Male & 22 & $1 \quad(5)$ & $21 \quad(95)$ & \\
\hline Female & 14 & $6(43)$ & $8 \quad(57)$ & \\
\hline Histology & & & & 0.060 \\
\hline SQ & 14 & 4 (29) & $10 \quad(71)$ & \\
\hline $\mathrm{AD}$ & 13 & 0 & $13(100)$ & \\
\hline $\mathrm{SCC}$ & 9 & $3(33)$ & $6 \quad(67)$ & \\
\hline p16INK4a protein & & & & \\
\hline expression $(\%)$ & & & & 1.000 \\
\hline$\geq 80$ & 9 & $2(22)$ & $(78)$ & \\
\hline$<80$ & 7 & 2 (29) & $(71)$ & \\
\hline$<10$ & 20 & $3(15)$ & $17 \quad(75)$ & \\
\hline p53 expression (\%) & & & & 0.468 \\
\hline$\geq 80$ & 5 & $2(40)$ & $(60)$ & \\
\hline$<80$ & 7 & 1 (14) & $6 \quad(86)$ & \\
\hline$<10$ & 24 & 4 (17) & $(83)$ & \\
\hline
\end{tabular}

B. Comparison between HPV-16 and non-16-related HPV positive tumors.

No. of the cases $(\%)$

HPV-16 Non-16-related HPV P-value ${ }^{b}$

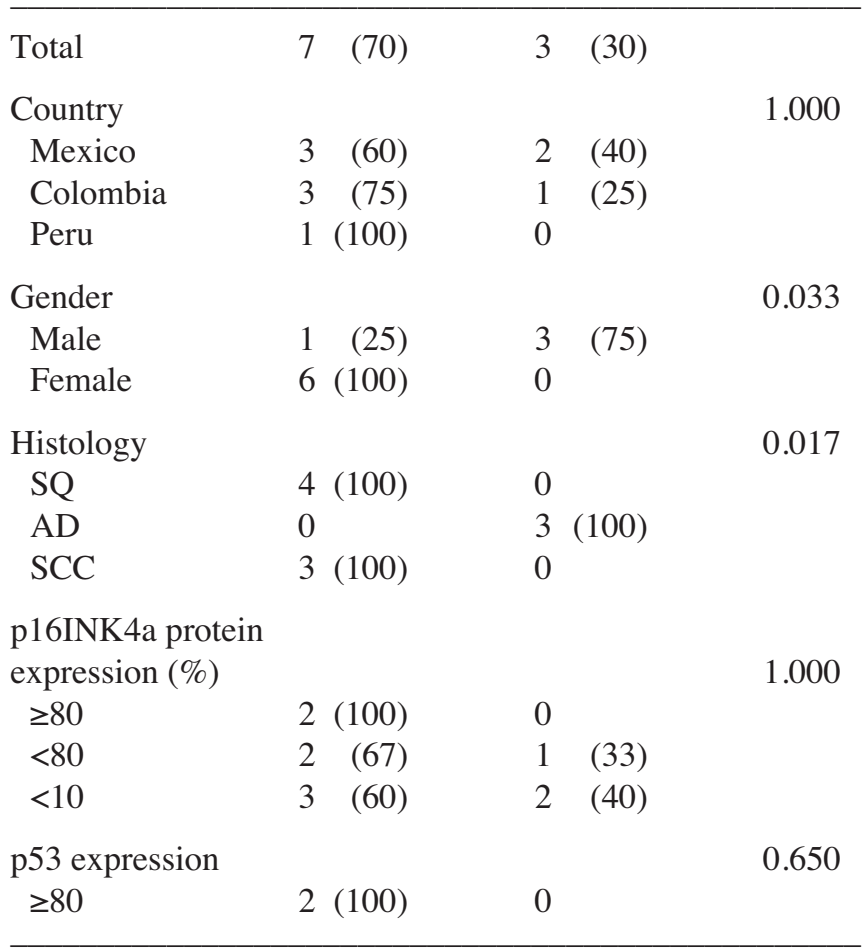

Table IV. B. Continued.

\begin{tabular}{lllll}
\hline & \multicolumn{4}{c}{ No. of the cases (\%) } \\
\cline { 2 - 3 } & HPV-16 & Non-16-related HPV P-value \\
\hline$<80$ & 1 & $(100)$ & 0 & \\
$<10$ & 4 & $(57)$ & 3 & $(43)$ \\
\hline
\end{tabular}

a HPV-16- HPV negative cases and non-16-related HPV positive cases; ' ${ }^{\mathrm{P}}$-values were obtained by Fisher's exact test; SQ, squamous cell carcinoma; AD, adenocarcinoma; SCC, small cell carcinoma.

Table V. HPV genotype distribution and the grade of tumor differentiation.

\section{Differentiation}

grade

No. HPV ${ }^{+}$HPV-16 HPV-18 HPV-33

\begin{tabular}{|c|c|c|c|c|c|}
\hline $\begin{array}{l}\text { Squamous cell } \\
\text { carcinomas }\end{array}$ & 14 & 4 & 4 & & \\
\hline Well & 1 & 1 & 1 & & \\
\hline Moderate & 6 & 1 & 1 & & \\
\hline Poor & 7 & 2 & 2 & & \\
\hline Adenocarcinomas & 13 & 3 & & 2 & 1 \\
\hline Well & 1 & 1 & & 1 & \\
\hline Moderate & 2 & & & & \\
\hline Poor & 10 & 2 & & 1 & 1 \\
\hline
\end{tabular}

6 out of 7 HPV-16 positive cases. The observed gender difference in the detection rate of HPV-16 was statistically significant $(\mathrm{P}=0.008$, Fisher's exact test). HPV-16 was not detected in any adenocarcinoma cases. HPV-16 was more frequently found in squamous cell carcinomas and small cell carcinomas of the lung but the observed histological difference was not statistically significant $(\mathrm{P}=0.060$, Fisher's exact test). On the other hand, HPV-18 and -33 were detected only among male cases, and all the HPV types detected in adenocarcinomas were 18 or 33 , and these HPV genotypes were detected only in this histological type (Table IV-B). The frequency of HPV-16 positive cases among all the HPV positive carcinomas differed in the sexes $(\mathrm{P}=0.033$, Fisher's exact test) and in the three histological types $(\mathrm{P}=0.017$, Fisher's exact test).

Table $\mathrm{V}$ shows the results examining the relationship between tumor differentiation levels and HPV presence. The level of tumor differentiation was not related to the presence of HPV-16 ( $\mathrm{P}=0.336$, Fisher's exact test) or non16-related HPV ( $P=0.266$, Fisher's exact test). When squamous cell carcinomas and adenocarcinomas were combined, the presence of HPV genome tended to be higher in welldifferentiated tumors. However, the tendency was not statistically significant ( $\mathrm{P}=0.093$, Fisher's exact test). 


\section{Discussion}

We found the HPV genome in $28 \%$ of lung carcinoma collected from three Latin American countries (Mexico, Colombia and Peru). The frequency was slightly lower than that reported from Chile (13) where the presence of HPV genome was observed in 6 of 13 squamous cell carcinoma cases $(42 \%)$. In the present study, HPV-16 predisposed to female cases $(\mathrm{P}=0.008)$ and to carcinomas other than adenocarcinomas $(\mathrm{P}=0.060)$. Its predisposition to non-adenocarcinomas became more evident when histological distributions of HPV-16 positive cases and other HPV positive cases were directly compared $(\mathrm{P}=0.017)$.

We could not detect HPV-6 or 11 genotype in any tumors examined. A population-based study conducted in Santiago, Chile, another Latin American country, showed a relatively low prevalence of HPV-6 and 11 genotypes (18). The four most common genotypes of low-risk HPV were HPV-42, 67, 70 , and 81 . Further investigations are necessary to examine common genotypes of low-risk HPV among the general populations of the three countries.

In the literature, the frequency of lung carcinomas with HPV genomic sequences shows a wide range, from none to almost $80 \%$, as reviewed by Gillison and Shan (6). Although these observations suggest the presence of geographic and demographic differences in HPV-related lung carcinoma, a factor involved in these inconsistent results is the method used for HPV detection. The review made by Syrjänen enables us to compare the detection rate by the methods used in those studies. PCR-agarose gel electrophoresis has higher detection rates than in situ hybridization. In the present study, HPV DNA was detected by PCR analysis using $G P 5^{+} / G P 6^{+}$primers, and the resulting products were analyzed by Southern blot hybridization with L1 gene labeled probe. When compared to PCR-agarose gel electrophoresis and in situ hybridization, which were frequently used in the studies reported so far (10) this method is considered to be more sensitive and enables us to detect HPV even when carcinoma cells have a small number of HPV copies.

In the present study, we detected 7 carcinomas with HPV-16 DNA; 6 of them were female cases. On the other hand, carcinomas with non-16-related HPV were limited to male cases. Cheng et al reported that lung carcinomas with HPV$16 / 18$ were much more frequently found among females than males (12). Their subsequent studies, using blood samples, tumor tissue and vaginal smear collected from the same lung cancer patients, made the following interesting findings: i) blood samples and lung tumors had similar HPV genotype distributions (19); ii) lung tumors and blood cells showed identical sequences of L1 and E6 of HPV-16/18 in their preliminary analysis and iii) the presence of HPV-16/18 in cervical pap smears of female lung cancer patients was correlated with those present in their lung tumors. On the basis of these findings, they suspect the possibility of HPV-16/18 transmission from uterine cervix to lung via blood circulation. Their hypothesis is not at variance with the predominance of HPV-16 in female lung carcinoma cases observed in the present study.

HPV E6 and E7 are considered to play important roles in the development and maintenance of malignant cells, and their expressions are regulated by cis-active elements in LCR, a long control region (20). HPV E6 interacts with p53 tumor suppressor and E6-associated protein, a host cell ubiquitin ligase, and induces accelerated proteasomal degradation of p53 (21). In lung carcinomas, Soini et al showed an inverse relationship between the presence of HPV DNA and abnormal p53 protein accumulation (22). On the other hand, binding of HPV E7 and pRb resulted in the release of E2F factors and the induction of high levels of p16 (23), and marked p16 overexpression was observed in cervical cancers (24). In the present study, however, we observed no tendency of p53 down-regulation or p16 up-regulation among HPV positive cases.

In the majority of carcinomas associated with high-risk HPV and some advanced HPV-associated precancerous lesions, the whole viral genome or its fragment is integrated into the chromosomal DNA of the host cell whereas the HPV genome is retained as episomal molecules in early dysplastic low-grade lesions. Although the mechanism involved in switching from episomal state to viral integration is yet unclear, it is suspected that methylation pattern on HPV genome is different in episomal and integrated states; Kim et al reported that the overall methylation status of the LCR was greater than that seen in the more highly differentiated cells (25). $\mathrm{Wu}$ et al also suspect that the involvement of HPV infection in lung tumorigenesis may be mediated at least in part through the increase of hypermethylation to cause p16INK4a inactivation (26). In addition, Sano et al pointed out that early-stage carcinomas showed p16 down-regulation, probably through hypermethylation, while its up-regulation is induced in late stages (24). We observed no relationship between HPV presence and p16 immunostaining.

In the uterine cervix, HPV-16 and -18 are the most commonly detected HPV genotypes in squamous cell carcinoma whereas HPV-18 is the most prevalent type in adenocarcinomas (2). In the present study, HPV-18 was detected in 2 adenocarcinoma cases and was not found in squamous cell carcinomas or small cell carcinomas of the lung, confirming the predisposition of HPV-18 to adenocarcinomas.

Miyagi et al reported that HPV involvement in cancer of the lung is most evident in well-differentiated squamous cell carcinomas (11), whose frequency has declined over the years (11). Overall, our findings are in agreement with what was reported by Miyagi et al (11). Indeed, we found HPV-16 only in squamous cell carcinomas and small cell carcinomas but not in adenocarcinomas. Due to a small number of cancer cases, it was difficult to examine the relationship between grades of tumor differentiation and HPV presence in each histological type. However, in the analysis where adenocarcinomas and squamous cell carcinomas were combined, HPV presence seemed to be related to tumor differentiation although the relationship was not statistically significant.

In conclusion, we detected high-risk HPV DNA in $28 \%$ of lung carcinomas. This percentage is similar to the value of $22 \%$ reported by a meta-analysis analyzing nearly 2500 lung carcinomas examined to date. HPV-16 predisposition to female cases and to carcinomas other than adenocarcinomas observed in the present study warrants further studies. 


\section{Acknowledgements}

This study was supported by Grants-in-Aid for Scientific Research on Priority Areas (12218231 and 17015037) of the Ministry of Education, Culture, Sports, Science and Technology, Japan.

\section{References}

1. Walboomers JM, Jacobs MV, Manos MM, Bosch FX, Kummler JA, Shah KV, Snijders PJ, Peto J, Meijer CJ and Munoz N: Human papillomavirus is a necessary cause of invasive cervical cancer world wide. J Pathol 189: 12-19, 1999.

2. Bosch FX, Manos MM, Munoz N, Sherman M, Jansen AM, Peto J, Schiffman MH, Moreno V, Kurman R and Shah KV: Prevalence of human papillomavirus in cervical cancer: a worldwide perspective. International biological study on cervical cancer (IBSCC) Study Group. J Natl Cancer Inst 87: 796-802, 1995.

3. Bosch FX, Lorincz A, Munoz N, Meijer C and Shah KV: The causal relationship between human papillomavirus and cervical cancer. J Clin Pathol 55: 244-265, 2002.

4. Snijders P, van den Brule A, Meijer C and Walboomers J: HPV and cancer of the aerodigestive tract. Papillomavirus Rep 6: 157-162, 1995.

5. Markham AF: Carcinoma of the lung: warts and all. Thorax 51: 878-879, 1996.

6. Gillison ML and Shan KV: Role of Mucosal Human Papillomavirus in Non-genital Cancers. J Natl Cancer Inst Monographs 31: 57-65, 2003.

7. IARC World Cancer Report. Stewart BW and Kleihaus P (eds). IARC Press, Lyon, 2003.

8. Syrjänen KJ: Condylomatous changes in neoplastic bronchial epithelium. Report of a case. Respiration 38: 229-304, 1979.

9. Syrjänen KJ: Epithelial lesions suggestive of a condylomatous origin found closely associated with invasive bronchial squamous cell carcinoma. Respiration 49: 150-160, 1980.

10. Syrjänen KJ: HPV infections and lung cancer. J Clin Pathol 55: 885-891, 2002.

11. Miyagi J, Tsuhako K, Kinjo T, Iwamawa T and Hirayasu T: Recent striking changes in histological differentiation and rate of human papillomavirus infection in squamous cell carcinoma of the lung I Okinawa: a subtropical island in Southern Japan. J Clin Pathol 53: 676-684, 2000.

12. Cheng YW, Chiou HL, Sheu GT, Hsieh LL, Chen JT, Chen CY, $\mathrm{Su}$ JM and Lee H: The association of human papillomavirus $16 / 18$ infection with lung cancer among nonsmoking Taiwanese women. Cancer Res 61: 2799-2803, 2001.

13. Aguayo F, Meneses M. Corvalán A, Muñoz M, Koriyama C, Eizuru Y and Akiba S: Identification of human papillomavirus 16 (HPV 16) in keratinizing lung carcinoma. Rev Chil Enferm Respire 18: 83-89, 2002.
14. Snijders PJ, van den Brule AJ, Schrijnemakers HF, Snow G, Meijer CJ and Walboomers JM: The use of general primers in the polymerase chain reaction permits the detection of a broad spectrum of human papillomavirus genotypes. J Gen Virol 71: 173-181, 1990.

15. De Roda Husman AM, Walboomers JM, van den Brule AJ, Meijer CJ and Snijders PJ: The use of general primers GP5 and GP6 elongated at their 3' ends with adjacent highly conserved sequences improves human papillomavirus detection by PCR. J Gen Virol 76: 1057-1062, 1995.

16. Ralhan R, Mathew R, Arora S, Bahl R, Shukla NK and Mathur M: Frequent alterations in the expression of tumor suppressor genes p16INK4A and pRb in esophageal squamous cell carcinoma in the Indian population. J Cancer Res Clin Oncol 126: 655-660, 2000.

17. Xu H, Lu DW, El-Mofty SK and Wang HL: Metachronous squamous cell carcinomas evolving from independent oropharyngeal and pulmonary squamous papilomas: association with human papillomavirus 11 and lack of aberrant p53, Rb, and p16 protein expression. Hum Pathol 35: 1419-1422, 2004.

18. Ferreccio C, Prado RB, Luzoro AV, Ampuero SL, Snijders PJ, Meijer CJ, Vaccarella SV, Jara AT, Puschel KI, Robles SC, Herrero R, Franceschi SF and Ojeda JM: Population-based prevalence and age distribution of human papillomavirus among women in Santiago, Chile. Cancer Epidemiol Biomarkers Prev 13: 2271-2276, 2004.

19. Chiou HL, Wu MF, Liaw YC, Cheng YW, Wong RH, Chen JT, Chen CY and Lee H: The presence of human papillomavirus type 16/18 DNA in blood circulation may act as a risk marker of lung cancer in Taiwan. Cancer 97: 1558-1563, 2003.

20. Howley PM and Lowy DR: Papillomavirus and their replication. In: Fields Virology. Knipe DM and Howley PM (eds). Lipppincott Williams \& Wilkins, Tokyo, pp2197-2229, 2001.

21. Barbosa MS: The oncogenic role of Human Papillomavirus Proteins. Crit Rev Oncogen 7: 1-18, 1996.

22. Soini Y, Kamel KN, Pollanen R, Vahakangas K, Lehto V and Paako P: Presence of human papillomavirus DNA and abnormal p53 protein accumulation in lung carcinoma. Thorax 51: 887-893, 1996.

23. Khleif SN, deGregori J, Yee C, Otterson GA, Kaye FJ, Nevins JR and Howley PM: Inhibition of cyclin D-CDK4/CDK6 activity is associated with an E2F-mediated induction of cyclin kinase inhibitor activity. Proc Natl Acad Sci USA 93: 4350-4354, 1996.

24. Sano T, Oyama T, Kashiwabara K, Fukuda T and Nakajima T: Expression status of p16 protein is associated with human papillomavirus oncongenic potential in cervical a genital lesions. Am J Pathol 153: 1741-1748, 1998.

25. Kim K, Garner-Hamrick PA, Fisher C, Lee D and Lambert PF: Methylation pattern of papillomavirus DNA, its influence on E2 function, and implication in viral infection. J Virol 77: 12450-12459, 2003

26. Wu MF, Cheng YW, Lai JC, Hsu MC, Chen JT, Liu WS, Chou MC, Chen CY and Lee H: Frequent p16INK4a promoter hypermethylation in human papillomavirus-infected female lung cancer in Taiwan. Int J Cancer 113: 440-445, 2005. 